\title{
New consensus macroeconomics and inflation targeting: Keynesian critique
}

\author{
Philip Arestis 1 \\ Malcolm Sawyer ${ }^{2}$
}

\begin{abstract}
A number of countries have adopted Inflation Targeting (IT) since the early 1990s in an attempt to reduce inflation to low levels. Since then, IT has been praised by most literature as a superior framework of monetary policy. We suggest that IT is a major policy prescription closely associated with the New Consensus Macroeconomics (NCM). This paper concentrates mainly on the IT aspects of the NCM. We address the theoretical foundations of IT. This is followed by an assessment of its theoretical foundations, where a number of aspects are discussed. We then turn our attention to an assessment of the empirical work on IT, where we distinguish the work that has been done utilising structural macroeconomic models, and work based in single equation techniques. The IT theoretical framework and the available empirical evidence do not appear to support the views of the proponents.
\end{abstract}

Key words: New consensus macroeconomics; Inflation targeting; Interest rates.

JEL E31, E52.

\section{Introduction}

A number of countries have adopted Inflation Targeting (IT) since the early 1990s in an attempt to reduce inflation to low levels. Since then, IT has been praised by most literature as a superior framework of monetary policy (Bernanke et al., 1999); and to quote a recent study, "The performance of inflation-targeting regimes has been quite good. Inflation-targeting countries seem to have significantly reduced both the rate of inflation and inflation expectations beyond that which would likely have occurred in the absence of inflation targets" (Mishkin, 1999, p. 595). ${ }^{3}$ Reducing the rate of inflation and inflation expectations are only but two of the benefits of IT, which the proponents cite. Further advantages have been mentioned. The most important may be briefly summarised: IT solves the dynamic time-inconsistency problem (when introduced alongside central bank 'independence'); it reduces inflation variability and it can also stabilise output if applied 'flexibly' (Svensson, 1997); it 'locks in' expectations of low inflation which helps to contain the possible inflationary impact of macroeconomic shocks; and while a number of countries have adopted the IT

(1) University of Cambridge. E-mail: pa267@ cam.ac.uk.

(2) University of Leeds. E-mail: mcs@lubs.leeds.ac.uk.

(3) Mishkin (1999, p. 595) is presumably using 'quite good' in the American sense of 'very good' rather than the British sense of 'moderately good'. 
Philip Arestis / Malcolm Sawyer

strategy, there does not seem to be a country that having adopted IT, abandoned it subsequently. ${ }^{4}$

Inflation targeting, as that term has become to be understood, involves rather more than just targeting the rate of inflation as an objective of economic policy. It is taken here to include the following: (i) the setting by government (normally) of a numerical target range for the rate of (price) inflation; (ii) the use of monetary policy as the key policy instrument to achieve the target, with monetary policy taking the form of interest rate adjustments; (iii) the operation of monetary policy in the hands of an 'independent' Central Bank; (iv) monetary policy only concerned with the rate of inflation, and the possible effects of monetary policy on other policy objectives is ignored, or assumed to be nonexistent, with the exception of short-term effects. The last item needs to be qualified in that not always it the case that IT central banks are so monolithic. The European Central Bank (ECB), for example, comes under the category of a 'single minded' central bank, in that it only pays regard to inflation. The Bank of England, by contrast, does not come under the same category. This is so in that its approach to IT policy appears to be concerned with a broader range of objectives, or at least makes some allowance for impact of interest rate changes on, for example, housing market. The Bank of England's symmetric approach to IT also implies concern with the costs of deflation being at least as great as the costs of inflation.

We suggest that IT is a major policy prescription closely associated with the New Consensus Macroeconomics (NCM). In a series of separate papers we discuss NCM along with its economic policy prescriptions in a general way, and conclude that monetary policy is upgraded while fiscal policy is downgraded within the confines of this paradigm (Arestis; Sawyer, 2003a, 2003b). In Arestis and Sawyer (2002) we deal with the properties of monetary policy within three macroeconometric models used by the ECB, the Bank of England and the Federal Reserve System (Fed). We conclude that at the empirical level the impact of changes in the rate of interest on inflation is weak in the long run, but that stronger effects are evident on investment. This paper concentrates mainly on the IT aspects of the NCM at both the theoretical and empirical levels. This is an exercise worth undertaking for two reasons. IT is an important theoretical and policy ingredient of NCM. Secondly, it has become a popular theoretical framework and policy tool; it has actually been adopted by a number of countries throughout the world (Fracasso et al., 2003, refer to 'more than 20 countries').

(4) One, of course, can argue that since the first country to have adopted it (New Zealand) only did so in 1990. It is, thus, too soon to declare the strategy as 'quite good'. Especially so in the rather 'serene' environment, which the 1990s decade enjoyed. 
We begin by addressing the theoretical foundations of IT in the section immediately below. This is followed by an assessment of its theoretical foundations, where a number of aspects are discussed. We then turn our attention to an assessment of the empirical work on IT, where we distinguish the work that has been done utilising structural macroeconomic models, and work based in single equation techniques. A final section summarises the argument and concludes.

\section{Inflation targeting and new consensus macroeconomics}

NCM can be described succinctly in the following three equations (see, for example, McCallum, 2001; Arestis and Sawyer, 2002):

$$
\begin{aligned}
& \text { (1) } \mathrm{Y}_{\mathrm{t}}^{\mathrm{g}}=\mathrm{a}_{0}+\mathrm{a}_{1} \mathrm{Y}_{\mathrm{t}-1}^{\mathrm{g}}+\mathrm{a}_{2} \mathrm{E}_{\mathrm{t}}\left(\mathrm{Y}_{\mathrm{t}+1}^{\mathrm{g}}\right)-\mathrm{a}_{3}\left[\mathrm{R}_{\mathrm{t}}-\mathrm{E}_{\mathrm{t}}\left(\mathrm{p}_{\mathrm{t}+1}\right)\right]+\mathrm{s}_{1} \\
& \text { (2) } \mathrm{p}_{\mathrm{t}}=\mathrm{b}_{1} \mathrm{Y}_{\mathrm{t}}^{\mathrm{g}}+\mathrm{b}_{2} \mathrm{p}_{\mathrm{t}-1}+\mathrm{b}_{3} \mathrm{E}_{\mathrm{t}}\left(\mathrm{p}_{\mathrm{t}+1}\right)+\mathrm{s}_{2} \\
& \text { (3) } \mathrm{R}_{\mathrm{t}}=\left(1-\mathrm{c}_{3}\right)\left[R R^{*}+\mathrm{E}_{\mathrm{t}}\left(\mathrm{p}_{\mathrm{t}+1}\right)+\mathrm{c}_{1} \mathrm{Y}_{\mathrm{t}-1}^{\mathrm{g}}+\mathrm{c}_{2}\left(\mathrm{p}_{\mathrm{t}-1}-\mathrm{p}^{\mathrm{T}}\right)\right]+\mathrm{c}_{3} \mathrm{R}_{\mathrm{t}-1}+\mathrm{s}_{3}
\end{aligned}
$$

with $b_{2}+b_{3}=1$, where $Y^{g}$ is the output gap, $R$ is nominal rate of interest, $\mathrm{p}$ is rate of inflation, $\mathrm{p}^{\mathrm{T}}$ is inflation rate target, $\mathrm{RR}^{*}$ is the 'equilibrium' real rate of interest, that is the rate of interest consistent with zero output gap which implies from equation (2), a constant rate of inflation, $s_{i}$ (with $i=1,2,3$ ) represents stochastic shocks, and $\mathrm{E}_{\mathrm{t}}$ refers to expectations held at time t. Equation (1) is the aggregate demand equation with the current output gap determined by past and expected future output gap and the real rate of interest. Equation (2) is a Phillips curve with inflation based on current output gap and past and future inflation. Equation (3) is a monetary-policy rule (defined by, for example, Svensson, 2003, p. 448, amongst others, as a 'prescribed guide for monetary-policy conduct'), which can be regarded as a replacement for the old LM-curve. In this equation, the nominal interest rate is based on expected inflation, output gap, deviation of inflation from target (or 'inflation gap'), and the 'equilibrium' real rate of interest. ${ }^{5}$ The lagged interest rate represents interest rate 'smoothing' undertaken by the monetary authorities, which is thought as improving performance by introducing 'history dependence' (see, for example, Rotemberg; Woodford, 1997; Woodford,

(5) In Taylor (1993) the original monetary-policy rule formulation was $\mathrm{Rt}=\mathrm{RR}^{*}+\mathrm{d} 1 \mathrm{Ygt}+\mathrm{d} 2\left(\mathrm{pt}-\mathrm{p}^{*}\right)$, where the symbols are as above, with the exception $\mathrm{p}^{*}$ which stands for the desired inflation rate, the coefficients are $\mathrm{d} 1=0.5$ and $\mathrm{d} 2=1.5$, $\mathrm{p}^{*}$ is 2 per cent and the average short term real interest rate is 2 per cent; so that $\mathrm{RR}^{*}$ is 4 per cent. d2 is required to be greater than one, the 'Taylor Principle', for unique equilibrium in sticky-price models (Taylor, 1999; Woodford, 2001). For a recent critique and further elaboration, as well as for a discussion of rules of monetary policy and a suggestion for describing IT as a 'forecast-targeting rule', or 'forecast targeting' (with the Reserve Bank of New Zealand being cited as an example of this procedure), see Svensson (2003). This is essentially what Blinder (1998) describes as 'dynamic programming' and 'proper dynamic optimization'. 
1999). ${ }^{6}$ There are three equations and three unknowns: output, interest rate and inflation.

This model has a number of additional, and relevant, characteristics. Equation (1) resembles the traditional IS function, but expenditure decisions are seen to be based on intertemporal optimization of a utility function. There are both lagged adjustment and forward-looking elements; the model allows for sticky prices (the lagged price level in the Phillips-curve relationship) and full price flexibility in the long run. The term $E_{t}\left(p_{t+1}\right)$ in equation (2) can be seen to reflect central bank credibility. If a central bank can credibly signal its intention to achieve and maintain low inflation, then expectations of inflation will be lowered and this term indicates that it may possible to reduce current inflation at a significantly lower cost in terms of output than otherwise. Equation (3), the operating rule, implies that 'policy' becomes a systematic adjustment to economic developments rather than an exogenous process. It stipulates that the nominal rate of interest is the sum of the real interest rate and expected inflation. As such, it incorporates a symmetric approach to inflation targeting. Inflation above the target dictates higher interest rates to contain inflation, whereas inflation below the target requires lower interest rates to stimulate the economy and increase inflation. Equation (3) contains a stochastic shock element, implying that monetary policy operates with random shocks; this is not always the case in the literature, where in some cases this element is not incorporated in equation (3) - see, for example, McCallum, 2001). ${ }^{7}$

The approach we have just briefly sketched can be viewed as 'new consensus' through its emphasis on a number of factors. The supply-side determined equilibrium level of unemployment (the 'natural rate' or the nonaccelerating inflation rate of unemployment, the NAIRU), its neglect of aggregate or effective demand and fiscal policy, as well as the elevation of monetary policy at the expense of fiscal policy, are the major factors.

(6) Variations on this theme could be used; for example, interest rate 'smoothing' in equation (3) is often ignored, as is the lagged output gap variable in equation (1) so that the focus is on the influence of expected future output gap in this equation. It is also possible to add a fourth equation to (1) - (3) reported in the text. This would relate the stock of money to 'demand for money variables' such as income, prices and the rate of interest, which would reinforce the endogenous money nature of this approach with the stock of money being demand determined. Clearly, though, such an equation would be superfluous in that the stock of money thereby determined is akin to a residual and does not feed back to affect other variables in the model. We have explored this issue and others related to whether the stock of money retains any causal significance at some length in Arestis and Sawyer (2003b).

(7) The model as a whole contains the neutrality of money property, with inflation determined by monetary policy (that is the rate of interest), and equilibrium values of real variables are independent of the money supply. The final characteristic we wish to highlight is that the stock of money has no role in the model; it is merely a 'residual'. In the simple model above, the stock of money makes no appearance: the addition of a demand for money equation would serve to indicate the stock of money determined by the demand for money. We have discussed this latter issue extensively in Arestis and Sawyer (2003a, 2003b). 
We postulate that the economics of IT are firmly embedded in equations (1) to (3), especially equation (3). This third equation entails an important aspect for IT, namely the role of 'expected inflation'. The inflation target itself and the forecasts of the central bank are thought of as providing a strong steer to the perception of expected inflation. The target and forecasts add an element of transparency seen as a paramount ingredient of IT. Consequently, inflation forecasting is a key element of IT; it can actually be thought of as the intermediate target of monetary policy in this framework (Svensson, 1997). The emphasis, however, on inflation forecasts entails a grave danger. This is due to the large margins of error in forecasting inflation, which can thereby damage the reputation and credibility of central banks. There can be a self-justifying element though to inflation forecasting in so far as inflation expectations build on forecasts, which then influence actual inflation. The centrality of inflation forecasts in the conduct of this type of monetary policy represents a major challenge to countries that pursue IT. Indeed, there is the question of the ability of a central bank to control inflation. Oil prices, exchange rate gyrations, wages and taxes, can have a large impact on inflation, and a central bank has no control over these factors. To the extent that the source of inflation is any of these factors, IT would have no impact whatsoever. Negative supply shocks are associated with rising inflation and falling output. A central bank pursuing IT would have to try to contain inflation, thereby deepening the recession. Even a central bank with both price stability (meaning low and stable inflation) and economic activity (meaning stabilizing output around potential output) objectives, would still behave in a similar fashion, simply because central banks are evaluated on their ability to meet inflation targets rather than output growth targets.

\subsection{Main features of inflation targeting}

There are certain features that form the key aspects of IT, which are embedded in equations (1) to (3) above. We discuss these features in this section. Before we embark upon this analysis, though, it is worth making the comment that inevitably different writers would emphasise different aspects of IT. We believe, however, that the features we summarise below is a set that most, if not all, of the proponents of IT would accept.

The key elements of IT may be summarised briefly as follows:

(i) IT is a monetary policy framework whereby public announcement of official inflation targets, or target ranges, is undertaken along with explicit acknowledgement that price stability, meaning low and stable inflation, is 
monetary policy's primary long-term objective (King, 2002b). ${ }^{8}$ Such a monetary policy framework, improves communication between the public, business and markets on the one hand, and policy-makers on the other hand, and provides discipline, accountability, transparency and flexibility in monetary policy. The focus is on price stability, along with three objectives: credibility (the framework should command trust) $;^{9}$ flexibility (the framework should allow monetary policy to react optimally to unanticipated shocks); and legitimacy (the framework should attract public and parliamentary support). A further advantage alluded to is that the role of IT might simply be to 'lock in' the gains from 'taming' inflation. Bernanke et al. (1999) are explicit on this issue, when they argue that "one of the main benefits of inflation targets is that they may help to 'lock in' earlier disinflationary gains particularly in the face of one-time inflationary shocks. We saw this effect, for example, following the exit of the United Kingdom and Sweden from the European Exchange Rate Mechanism and after Canada's 1991 imposition of the Goods and Services Tax. In each case, the re-igniting of inflation seems to have been avoided by the announcement of inflation targets that helped to anchor the public's inflation expectations and to give an explicit plan for and direction to monetary policy" (p. 288).

(ii) The objectives of the IT framework are achieved through the principle of 'constrained discretion' (Bernanke; Mishkin, 1997, p. 104), rather than 'unfettered discretion' (King, 1997b). ${ }^{10}$ This principle constrains monetary policy to achieve clear long-term and sustainable goals, but discretion is allowed to respond sensibly to unanticipated shocks. In this way, IT serves as a nominal anchor for monetary policy, thereby pinning down precisely what the commitment to price stability means. As such, monetary policy imposes discipline on the central bank and the government within a flexible policy framework. For example, even if monetary policy is used to address short-run stabilization objectives, the

(8) Inflation targeting in this policy framework is preferred to money supply targeting. This is due to the instability of the LM because of the unstable demand-for-money relationship (see, for example, HM Treasury, 2003). It can also be seen to target a final rather than intermediate objective. See, also, King (1997) who argues for the superiority of IT over a money-supply rule, in that it results in optimal short-run response to shocks, in a way that money-growth targeting does not (see, also, Svensson; Woodford, 2003).

(9) Credibility is recognised as paramount in the conduct of monetary policy to avoid problems associated with time-inconsistency (Barro; Gordon, 1983). It is argued that a policy, which lacks credibility because of time inconsistency, is neither optimal nor feasible (Kydland; Prescott, 1977; Calvo, 1978; Barro; Gordon, 1983).

(10) 'Constrained discretion' is actually viewed as 'middle ground' between 'rules' and 'discretion'. It is "an approach that allows monetary policymakers considerable leeway in responding to economic shocks, financial disturbances, and other unforeseen developments. Importantly, however, this discretion of policy makers is constrained by a strong commitment to keeping inflation low and stable" (Bernanke, 2003a, p. 2). In other words, IT can help "to reduce the inefficiencies resulting from the time-consistency problem and can incorporate new ideas into a discretionary monetary strategy constrained by a mandate that has widespread support in the population as a whole". This framework "of 'constrained discretion' for central banks is farremoved from the world of 1930 when the Deputy Governor of the Bank of England explained to the Macmillan Committee that 'it is a dangerous thing to start to give reasons"” (King, 2004a, p. 19). 
long-run inflation objective must not be compromised, thereby imposing consistency and rationality in policy choices (in doing so, monetary policy focuses public's expectations and provides a reference point to judge short-run policies). Such an approach, it is argued, makes it less likely for deflation to occur. Indeed, "Targeting inflation rates of above zero, as all inflation targeters have done, makes periods of deflation less likely" (Mishkin, 2000, p. 5).

(iii) Monetary policy is taken as the main instrument of macroeconomic policy. The view is that it is a flexible instrument for achieving medium-term stabilisation objectives, in that it can be adjusted quickly in response to macroeconomic developments. Indeed, monetary policy is viewed as the most direct determinant of inflation, so much so that in the long run the inflation rate is the only macroeconomic variable that monetary policy can affect. Monetary policy cannot affect economic activity, for example output, employment etc., in the long run. The achievement of the long-run objective of price stability should take place at a minimum cost in terms of the output gap (deviation of actual from potential output) and deviations of inflation from target (HM Treasury, 2003).

(iv) Fiscal policy is no longer viewed as a powerful macroeconomic instrument (in any case it is hostage to the slow and uncertain legislative process). It has a passive role to play in that the budget deficit position varies over the business cycle in the well-known manner. The budget (at least on current account) can and should be balanced over the course of the business cycle. An implication of this argument is that "Restraining the fiscal authorities from engaging in excessive deficits financing thus aligns fiscal policy with monetary policy and makes it easier for the monetary authorities to keep inflation under control" (Mishkin, 2000, p. 2). In this way, "monetary policy moves first and dominates, forcing fiscal policy to align with monetary policy" (Mishkin, op. cit., p. 4). ${ }^{11}$

(v) Monetary policy has, thus, been upgraded and fiscal policy has been downgraded. It is recognized that the budget position will vary over the course of the business cycle in a counter cyclical manner (that is deficit rising in downturn, surplus rising in upturn), which helps to dampen the scale of economic fluctuations (i.e. act as an 'automatic' stabilizer). But these fluctuations in the budget position take place around a balanced budget on average over the cycle. Such a strong fiscal position reinforces the credibility of the IT framework, thereby limiting the real costs to the economy of keeping inflation on target.

(11) An anonymous referee has raised the issue that in our discussion we give the impression that certain aspects are precluded from the IT framework. Fiscal policy is referred to as the main example of this charge. We agree entirely with the referee's contention and we would argue that fiscal policy can in principle be upgraded and used in conjuction with monetary policy, in a close co-ordination of the two policies. But, and as stated in the text, a number of IT proponents would dissent from this view (Mishkin, 2000, is a very good example in this context). 
(vi) Monetary policy can be used to meet the objective of low rates of inflation (which are always desirable in this view, since low, and stable, rates of inflation are conducive to healthy growth rates). However, monetary policy should not be operated by politicians but by experts (whether banks, economists or others) in the form of an 'independent' central bank. ${ }^{12}$ Indeed, those operating monetary policy should be more 'conservative', that is place greater weight on low inflation and less weight on the level of unemployment than the politicians (Rogoff, 1985). Politicians would be tempted to use monetary policy for shortterm gain (lower unemployment) at the expense of long-term loss (higher inflation); this is the time-inconsistency problem to which we referred earlier (see footnote 3 above). An 'independent' central bank would also have greater credibility in the financial markets and be seen to have a stronger commitment to low inflation than politicians do.

(vii) The level of economic activity fluctuates around a supply-side equilibrium. In the model outlined above this equilibrium corresponds to $\mathrm{Y}^{\mathrm{g}}=0$ (and inflation is equal to target rate, and real interest rate is equal to $\mathrm{RR}^{*}$ ). This can be alternatively expressed in terms of the non-accelerating inflation rate of unemployment (the NAIRU) such that unemployment below (above) the NAIRU would lead to higher (lower) rates of inflation. The NAIRU is a supply-side phenomenon closely related to the workings of the labour market. The source of domestic inflation (relative to the expected rate of inflation) is seen to arise from unemployment falling below the NAIRU, and inflation is postulated to accelerate if unemployment is held below the NAIRU. However, in the long run there is no trade-off between inflation and unemployment, and the economy has to operate (on average) at the NAIRU if accelerating inflation is to be avoided. In the long run, inflation is viewed as a monetary phenomenon in that the pace of inflation is aligned with the rate of interest. Monetary policy is, thus, in the hands of central bankers. Control of the money supply is not an issue, essentially because of the instability of the demand for money that makes the impact of changes in the money supply a highly uncertain channel of influence.

(viii) The essence of Say's Law holds, namely that the level of effective demand does not play an independent role in the (long run) determination of the level of economic activity, and adjusts to underpin the supply-side determined level of economic activity (which itself corresponds to the NAIRU). Shocks to the level of demand can be met by variations in the rate of interest to ensure that

(12) The distinction between goal independence and instrument independence is made (Debelle and Fischer, 1994; Fischer, 1994). Two examples make the point: the Bank of England has instrument independence (it sets the rate of interest as sees appropriate), but not goal independence (the goal, or inflation target is set by the Chancellor of the Exchequer. The ECB has both goal and instrument independence. The IT proponents usually argue for goal dependence, in that it is more democratic for the government to set the goal of price stability, and for the central bank to pursue that goal by independently setting the instrument(s) of monetary policy (see, for example, Bernanke et al., 1999). 
inflation does not develop (if unemployment falls below the NAIRU). The implication of this analysis is that there is a serious limit on monetary policy. This is that monetary policy cannot have permanent effects on the level of economic activity; it can only have temporary effects, which are serially correlated. This implies further that a change in monetary stance would have temporary effects, which will persist for a number of periods before they completely dissipate in price adjustments.

\section{An assessment of the theoretical foundations of inflation targeting}

We attempt to assess the IT framework in this section, from a number of angles. This entails a series of discussions that need not be integrated but, nonetheless, focus on aspects of the IT framework that we believe are crucial to its development. The following aspects are covered: IT as a nominal anchor; the separation of real and monetary factors; causes of inflation as seen by IT supporters; and concerns with asset pricing.

\subsection{The nominal anchor}

An important criticism is that adoption of a nominal anchor, such as an inflation target, does not leave much room for manoeuvre for output stabilisation. As discussed above, this is viewed by most, though not all, proponents as possible in the short run (but not an issue in the long run since output returns to its equilibrium level). It is true, though, that there are supporters of IT who argue quite conspicuously that monetary policy should concentrate on both output and price fluctuations. Bernanke (2003b) follows Meyer (2001) in drawing the distinction between a hierarchical mandate, in which all objectives are subordinate to price stability, and dual mandate, where the economic activity and price stability objectives are adhered to equally. Both Bernanke (op. cit.) and Meyer (op. cit.) support the dual mandate; indeed, Bernanke suggests that "Formally, the dual mandate can be represented by a central bank loss function that includes both inflation and unemployment (or the output gap) symmetrically" (p. 10). ${ }^{13}$ Others argue that central bankers should not become 'inflation nutters' (King, 2002a). Mishkin (2000) is clear on the issue, "the objectives for a central bank in the context of a long-run strategy should not only include minimizing inflation fluctuations, but should also include minimizing output fluctuations" (p. 3). This is known as 'flexible inflation targeting' (Svensson, 1999). Even when inflation is the only target, it is shown (Svensson, 1997; Rudebusch; Svensson, 1999) that it is optimal to respond to the determinants of the target variable, current inflation and

(13) Bernanke (2003a) has actually argued that "In practice ..... this approach has allowed central banks to achieve better outcomes in terms of both inflation and unemployment, confounding the traditional view that policymakers must necessarily trade off between the important social goals of price stability and high employment" (p. 2).

Economia e Sociedade, Campinas, v. 17, Número especial, p. 629-653, dez. 2008. 
the output gap, rather than to the target itself. This is so, since both inflation and output gap determine future inflation. More recently, Svensson (2003) argues for 'forecast targeting' (see, also, footnote 3 above), which is meant as "a commitment to minimize a loss function over forecasts of the target variables" (p. 451). The loss function contains forecasts for both inflation and output gap as target variables. ${ }^{14}$ However, price stability is the overriding goal in the view of the IT proponents. When Mishkin (2000) refers to the experience of the USA Federal Reserve System, he argues the "lack of a clear mandate for price stability can lead to the time-inconsistency problem in which political pressure is put on the Fed to engage in expansionary policy to pursue short-run goals" (p. 8).

Ultimately, though, proponents utilise the dual mandate notion in a specific way. For example, Bernanke (2003a) states the case in the following manner: "The essence of constrained discretion is the general role of a commitment to price stability. Not only does such a commitment enhance efficiency, employment, and economic growth in the long run, but - by providing an anchor for inflation expectations - it also improves the ability of central banks to stabilize the economy in the short run as well" (p. 10). So, output stabilization is a short-run possibility. However, Meyer (2001) takes a different view, which denies the long-run concern with only price stability. It is suggested that "this view is misleading in a couple of respects. First, monetary policymakers should be concerned about two long-run properties of the economy. One is price stability and the other is the variability of output around full employment. Policy has to be judged by its success in both dimensions. Second, policy is made in the short run, not the long run. The speed of return of output to its potential level is influenced by policy decisions and cannot be treated with indifference. It may just take too long and waste too many resources in the interim to rely on the self-equilibrating forces of the economy. Policymakers will therefore have to take into account, in practice, both objectives in their policy actions" (p. 8).

There is an important related issue, namely the desirability of low inflation within the context of the IT framework. It is generally assumed within the IT framework, that lower inflation is always more desirable than higher inflation, and that lower inflation can be achieved without any loss of output (as embedded in the framework of equations above). This should be judged against evidence provided by Ghosh and Phillips (1998), where a large panel set that covers IMF countries over the period 1960-96 is utilised, to conclude that "there are two

(14) Svensson (2003) identifies two problems with a general 'forecast targeting'. The first is the extent to which the objectives of the central bank are well specified. For example, central banks do not specify directly a weight for the output-gap target as they should. The second problem is that such an approach may not be fully 'optimal' in a forward-looking environment, although this problem "can potentially be solved by a commitment to a specific targeting rule" (Svensson, 2003, p. 455). 
important nonlinearities in the inflation-growth relationship. At very low inflation rates (around 2-3 percent a year, or lower), inflation and growth are positively correlated. Otherwise, inflation and growth are negatively correlated, but the relationship is convex, so that the decline in growth associated with an increase from 10 percent to 20 percent inflation is much larger than that associated with moving from 40 per cent to 50 per cent inflation" (p. 674). However, the point at which the nonlinearity changes from positive to negative is thought to deserve a great deal more research. The IT argument should also be judged in terms of statements like "there is an optimal rate of inflation, greater than zero. So ruthless pursuit of price stability harms economic growth and well-being. Research even questions whether targeting price stability reduces the trade-off between inflation and unemployment" (Stiglitz, 2003; see, also, Akerlof et al., 1996).

\subsection{The separation of real and monetary factors}

The points just made about the desirability of low inflation are closely linked with the view that there is a separation of real and monetary factors in the economy. The assignment can then be made: monetary policy to the nominal side of the economy, and specifically to inflation, and supply-side policies to address the real side of the economy (and often, though not an intrinsic part of IT, labour market policies to address problems of unemployment). King (1997a), now the Governor of the Bank of England, argues that "if one believes that, in the longrun, there is no trade-off between inflation and output then there is no point in using monetary policy to target output. .... [You only have to adhere to] the view that printing money cannot raise long-run productivity growth, in order to believe that inflation rather than output is the only sensible objective of monetary policy in the long-run" (p. 6).

The supply-side of the economy is often represented in terms of an unchanging supply-side equilibrium. For example, the 'natural rate of unemployment' or the NAIRU is used to summarise the supply-side equilibrium, and the estimates provided of the 'natural rate' or the NAIRU are often presented as a single (and hence implicitly unchanging) number. In the three equations above, the supply-side equilibrium is represented as a zero output gap. A less extreme view would be that the supply-side equilibrium may change over time but not in response to the demand side of the economy. Changes in labour market institutions and laws, for example, would be predicted to lead to changes in the supply-side equilibrium. In the context of IT, the significant question is whether interest rates through their effect on the level of aggregate demand have any lasting impact on the supply side of the economy.

It can first be noted that the estimates of the NAIRU (or equivalent) do often vary over time. Gordon (1997) has, for example, provided estimates of a 
time-varying 'natural rate of unemployment' drawn from evidence on the relationship between price inflation and the rate of unemployment. The OECD produces estimates of the non-accelerating wage rate of unemployment (NAWRU) on a bi-annual basis (see, OECD Economic Outlook database). These estimates of the NAWRU for a range of countries provide evidence that the estimated NAWRU varies over time and differs substantially across countries. It does not, of course, tell us the factors, which have lead to these changes. ${ }^{15}$

\subsection{The causes of inflation}

This 'new consensus' focuses on the role of monetary policy (in the form of interest rates) to control demand inflation, and not cost inflation, as is evident from equation (2). As Gordon (1997) remarked (though not in the context of this 'new consensus'), "in the long run inflation is always and everywhere an excess nominal GDP phenomenon. Supply shocks will come and go. What remains to sustain long-run inflation is steady growth of nominal GDP in excess of the growth of natural or potential real output" (p. 17). The position taken by IT on cost inflation is that it should either be accommodated, or that supply shocks come and go - and on average are zero and do not affect the rate of inflation (see, for example, Clarida; Galí; Gertler, 1999). The significance of the IT on this score is that it strongly suggests that inflation can be tamed through interest rate policy (using demand deflation). In addition, there is an equilibrium rate (or 'natural rate'), which is feasible, and can balance aggregate demand and aggregate supply and lead to a zero gap between actual and capacity output.

In the context of the working of monetary policy, this view of inflation, namely that it is caused by demand factors, raises two issues. The first is the question of how effective monetary policy is in influencing aggregate demand and thereby inflation. This touches on the relevant empirical evidence, and we tackle this issue in section 4 where we conclude that it does not support the IT contentions. If inflation is a 'demand phenomenon', and not a cost phenomenon, as reflected in the Phillips curve of equation (2), then the question arises as to whether monetary policy is the most effective (or least ineffective) way of influencing aggregate demand. Second, there is the question of whether the possibility of sustained cost-push and other non-demand related inflation could be as lightly dismissed, as the 'new consensus' appears to do. The version of the Phillips curve which appears as equation (2), is a (heavily) reduced form that does not explicitly consider wages, material costs and imported prices. A sustained money wage push makes no appearance in equation (2) and it would appear that there is no explicit representation of such pressures. An increase in, for example,

(15) It should also be noted that these are estimates of the NAWRU, which come from the econometric estimation of a model of the economy, and hence the estimates are reliant on the model used. 
wage aspirations on the part of workers or pressure for higher profit margins are not incorporated, though it could be argued that they would be reflected in the stochastic term.

This may be acceptable if pressures for higher wages and profit margins varied in a stochastic fashion over time (and averaged to zero). But even a sequence of time periods in which wage or profit margin pressures were positive, reflected in positive stochastic terms in equation (2), would have long lasting effects as one period's inflation feeds through to subsequent periods inflation (through the lagged inflation term in equation 2). Similarly if expectations on inflation were to rise (for whatever reason), then inflation would rise according to equation (2), and subsequent inflation would also be higher than otherwise. In the event of a sustained increase in inflation (due to cost pressures, as would seem to have been the case during the 1970s), this could only be met, in this framework, by raising interest rates and grinding down inflation by low demand and high unemployment.

\subsection{Asset pricing}

Asset pricing raises a related critical argument in that IT is an insufficient guide for monetary policy in view of balance-sheets disorders (Palley, 2003). These imbalances are more likely to occur in today's environment of deregulated financial markets, essentially due to their ability to innovate. The imbalances thereby created are not expected to have immediate effects on inflation, but can have significant employment and output costs. These disorders are asset price and debt bubbles, which IT cannot cure. The implication being that additional policy measures are required; IT by itself cannot achieve the objectives assigned to it. Furthermore, IT can create moral hazard in asset markets (Palley, op. cit.). Monetary authorities pay little attention during the upturn, but are compelled to protect asset values during the downturn. King (2002b) and Bean (2003) suggest that IT may need to be extended to avoid financial imbalances. This raises the issue of asset price targeting.

The standard argument in terms of asset price control is that asset price inflation (the percentage yearly change in equity prices, house prices or land prices) is out of the realm of central banks, as it reflects market forces and any control is widely regarded as infringing with the principles of the free market economy, or, indeed, it is the result of 'irrational exuberance'. Bernanke and Getler (2000) argue that trying to stabilise asset prices is problematic, essentially because it is uncertain whether a given change in asset values results from fundamental or non-fundamental factors or both. In this thesis, proactive monetary policy would require the authorities to outperform market participants. Inflation targeting in this view is what is important, where policy should not respond to 
changes in asset prices. Clews (2002) argues along similar lines, and concludes that asset price movements "rarely give simple unequivocal messages for policy on their own" so that they are "unlikely to be suitable as intermediate targets for a policy whose main aim is to control inflation" (p. 185). Greenspan (2002) argues that the size of the change in the rate of interest to prick a bubble may be substantial and harmful to the real economy.

An interesting proposal is contained in the study by Bordo and Jeanne (2002). Using a stylised model they examine the possibility of pre-emptive monetary policy to conclude that "optimal policy depends on the economic conditions in a complex, non-linear way and cannot be summarized by a simple policy rule of the type considered in the inflation-targeting literature" (p. 1). Still another view maintains that "although there are justifiable concerns about recent movements in asset prices, the policy dilemma can be analysed within the framework of inflation targeting that we have in the UK" (King, 2002b, p. 16). In any case, "It is hard to forecast asset price movements accurately or to identify asset price 'bubbles'. Even if we could identify them, it is not clear how effectively we could in practice control them" (King, 2004b, p. 4).

Yet the experience of many countries shows that successful control of CPI-inflation does not guarantee low asset price inflation - witness the late 1990s US experience, for example (Arestis and Karakitsos, 2004). When asset price inflation gets out of control bubbles are built and while they grow they generate a lot of euphoria. But bubbles have ultimately burst with devastating consequences not only for the investors in the stock markets, but also for the economy as a whole. The experience of the last twenty years shows that the adverse consequences of the burst of a bubble hit not only weak economies, but also strong economies such as the US and Japan. Monetary policy should, therefore, target asset prices in addition to inflation (Dupor, 2002; Cecchetti et al, 2000). Goodhart's (2001) suggestion, based on Alchian and Klein (1973), and in contrast to Bernanke and Getler, 2000), that central banks should consider housing prices and, to a lesser extent, stock market prices in their policy decisions, is very pertinent.

\section{Empirical aspects of inflation targeting}

We begin this section with an 'empirical' observation made by Blinder (1998) on the practice of undertaking monetary policy within the IT framework by committees. This critique has been taken up by Blinder (1998) who argues that committees "laboriously aggregate individual preferences ... need to be led ... tend to adopt compromise positions on difficult questions ... tend to be inertial" (p. 20). Committee inertial behaviour, in particular, may induce the awkward problem of "inducing the central bank to maintain its policy stance too long" 
thereby causing central banks "to overstay their stance" (Blinder. 1998, p. 20). This problem may be alleviated whenever there is a strong and powerful chairman of the monetary policy committee, but even then "a chairman who needs to build consensus may have to move more slowly than if he were acting alone" (p. 21). This is a serious charge in that it emanates from somebody who has had a great deal of experience of committees setting monetary policy.

We move on next to discuss two types of empirical evidence concerning the impact of interest rate changes. We first draw on evidence that is based on macroeconometric models, and utilise some previous work in which we summarised a range of evidence. This is followed by evidence that emanates from the application of single equation techniques.

\subsection{Empirical evidence based on macroeconometric models}

It is important to be able to assess quantitatively the effects of monetary policy. This raises immediately the question of the channels through which the impact of monetary policy is transmitted through the economy. Whatever these channels might be, they are not mutually exclusive, in that the overall response of the economy to changes in monetary policy incorporates the combined effects of all the channels. This concurrent operation of multiple channels entails an important challenge, namely that it becomes very difficult to assess the strength and contribution of the individual channels to the overall impact of monetary policy on the inflation rate. A further and related problem is that of isolating the change in the strength and importance of the channels of monetary transmission through time. The evolutionary nature of these changes and that many of the structural changes occur concurrently, are additional problems. The most serious difficulty in this context is the fact that these changes and any of their effects on the transmission mechanism take relatively long periods to become evident. All in all, the aspects we have just discussed clearly imply that the link between monetary policy and the real economy changes over time (see Kuttner; Mosser, 2002, especially p. 17-18). Evidence that the monetary transmission itself has changed, has been provided by Boivin and Giannoni (2003a), using VARs in the case of the USA for the period 1960 to 2001, and by Boivin and Giannoni (2003b) where a small-scale structural model is employed.

An additional, and as serious a challenge, is that of simultaneity. Central banks normally relax policy in the wake of weaknesses in the economy and tighten policy when there are strengths in the economy. Put it in another way, "how is it possible to isolate the effect of interest rates on economic conditions when interest rates are themselves a function of economic conditions" (Kuttner; Mosser, 2002, p. 23). This potentially endogenous response of policy to economic conditions is another serious impediment to any attempt to identify and isolate the effects of the 
different monetary transmission channels. It is paramount to bear in mind these observations in the attempt to assess the quantitative effects of monetary policy. ${ }^{16}$

Given the observations just made, in Arestis and Sawyer (2002) we attempted to gauge quantitatively the strength of interest rate changes through reporting the results dynamic simulations carried out by others in the case of three macroeconometric models currently used in official economic policy making. These are the macroeconometric models of the European Central Bank, the Bank of England and the USA Federal Reserve System (Bank of England, 1999, 2000; Van Els et al., 2001; Angeloni et al., 2002). The conclusions we draw from this exercise are along the following lines. First, (at least within the context of the macroeconometric models) there are constraints to a permanent change in the rate of interest. We would see the effect of interest rate on the exchange rate (when interest rate parity is assumed) as being a significant element in this (in that an interest differential between the domestic interest rate and foreign interest rate leads to a continual change in the exchange rate). However, we remain sceptical of the empirical validity of that link. This is so in view of the difficulty that exchange rate movements have proved near impossible to model satisfactorily. The theory indicates a close relationship between interest rate differentials and expected exchange rate movements, which would severely limit variations in interest rates. However, the model does not seem to work empirically. In fact, it is true to say that exchange rate variations have proved notoriously difficult to model, regardless of the theoretical framework one might adopt. Second, and this is clear in the case of the euro area models, when interest rates have an effect on aggregate demand this comes through from substantial changes in the rate of investment. This means that interest rate variations can have long lasting effects, in that the effects on investment will lead to changes in the size of the capital stock. Third, the effects of interest rate changes on the rate of inflation are rather modest. A 1 percentage point change in interest rates is predicted to lead to a cumulative fall in the price level of 0.41 per cent in one case and 0.76 per cent in the other, after five years. The rate of inflation declines by a maximum of 0.21 percentage points.

The component of aggregate demand, which is likely to be the most interest sensitive, is investment expenditure. This is supported by the results of the simulations of the effects of interest rate policy to which reference is made below in which the effect of interest rate change on investment is larger than the effects on other components of demand. The IT framework is concerned with the effects of interest rate on aggregate demand, and thereby on the rate of inflation. But it is, of course, the case that investment impacts on the time path of the capital stock, and hence on the future supply-side position. For monetary policy to have no lasting supply side effects, it would have to be assumed that the real rate of interest

(16) See Federal Reserve Bank of New York (2002) for more details on the problems and issues discussed in the text. 
averaged out at the equilibrium rate, and that the effects of interest rates (relative to the equilibrium rate) were symmetrical. Even then there would be effects on investment, which would last for some time (e.g. perhaps 20 years, depending on the life of the capital stock). But this would imply that the reduction of inflation through deflationary monetary policy and higher interest rates would have a longlasting effect on the capital stock.

We conclude from this brief excursion of the potential impact of interest rate changes that there is very little support of its most important tenet. Changes in the rate of interest are not expected to have the impact assigned to them by the theoretical propositions of the IT model. We next look at the evidence based on the application of the VAR technique.

\subsection{Empirical evidence based on single equation techniques}

A number of studies have reviewed the empirical work undertaken on IT, when single equation econometric techniques are employed. The studies reviewed ask a number of questions with the most pertinent being the following: whether IT improves inflation performance and policy credibility, and whether the sacrifice ratio, i.e. the cost of lowering inflation, does not increase significantly over the period of IT implementation. In the mid-1990s, Leiderman and Svensson (1995) reviewed the early experience with IT, with, however, rather limited number of observations. Later studies (Bernanke et al., 1999; Corbo et al., 2001, 2002; Clifton et al., 2001; Arestis et al., 2002; Johnson, 2002; Neumann; von Hagen, 2002) inevitably afforded longer periods and more data. A reasonably comprehensive review of the empirical literature on IT (Neumann and von Hagen, 2002), concludes in the same manner as the other studies before it had done. We may summarise these conclusions quite briefly. This evidence supports the contention that IT matters. Those countries which adopted IT, managed to reduce inflation to low levels and to curb inflation and interest rate volatility. Indeed, "Of all IT countries it is the United Kingdom that has performed best even though its target rate of inflation is higher than the inflation targets of most other countries" (Neumann; von Hagen, p. 144). ${ }^{17}$

The evidence, however, is marred by three weaknesses (Neumann; von Hagen, 2002): the first is that the empirical studies reviewed fail to produce convincing evidence that IT improves inflation performance and policy credibility, and lowers the sacrifice ratio. After all the environment of the 1990s was in general terms a stable economic environment, "a period friendly to price stability" (Neumann; von Hagen, 2002, p. 129). So that IT may have had little impact over

(17) Anecdotal evidence has also been propounded to make the IT case. Bernanke (2003) suggests that "central banks that have switched to inflation targeting have generally been pleased with the results they have obtained. The strongest evidence on that score is that, thus far at least, none of the several dozen adopters of inflation targeting has abandoned this approach" (p. 1). 
Philip Arestis / Malcolm Sawyer

what any sensible strategy could have achieved; indeed, non-IT countries also went through the same experience as IT countries (Cecchetti; Ehrmann, 2000). The second weakness is that despite the problem just raised, that of lack of convincing evidence, the proponents argue very strongly that non-adoption of IT puts at high risk the ability of a central bank to provide price stability (for example, Bernanke et al., 1999, 'submit a plea' for the Fed to adopt it; also Alesina et al., 2001, make the bold statement that the European Central Bank could improve its monetary policy by adopting IT; both studies do not provide any supporting evidence, though). And yet, both the Fed and the European Central Bank remain highly sceptical (Gramlich, 2000, and Duisenberg, 2003, do not actually regard IT appropriate for the USA and the euro area, respectively). The third weakness refers to the argument that in a number of countries (for example, New Zealand, Canada and the UK) inflation had been 'tamed' well before introducing IT (Mishkin; Posen, 1997).

In the same paper, the authors produce further evidence, which enables them to conclude that IT has proved an effective 'strategy' in the fight against inflation. This is based on the argument that whenever IT was adopted, countries experienced low inflation rates, along with reduces volatility of inflation and interest rates. However, the evidence produced by the same study cannot support the contention that IT is superior to money supply targeting (for example, the Bundesbank monetary targeting between 1974 and 1998), or to the Fed's monetary policy in the 1980s and 1990s (which has pursued neither a monetary nor an inflation targeting policy. A further finding of this paper is that Taylor rules suggest that central banks focus more on the control of inflation after adopting inflation targeting, thereby implying that price stability will be achieved. A result supported by the VAR evidence, which indicates that the relative importance of inflation shocks as a source of the variance of interest rates rises after adoption of inflation targeting.

Mishkin (2002) in discussing Neumann and von Hagen (2002), however, points out that since both short-term and long-term coefficients on inflation in the Taylor rules estimated relationships, are less than 1, the inflation process is highly unstable. The implication here is that when there is an increase in inflation the central bank raises the rate of interest by a smaller amount, thereby reducing the real rate of interest. This is of course an inflationary move by the central bank when the opposite was intended. This is also true for the non-IT countries, like the USA, a result that is contrary to Taylor's (1993) finding, who argues that for the USA it is greater than 1 in the post-1979 period when allegedly monetary policy performance improved relative to the pre-1979 period.

Mishkin (2002) identifies another interesting problem, which relates directly to the VAR approach. This is that since this approach does not contain any structural model of dynamics, the interpretation that inflation shocks contribute to 
the variance of interest rates need not imply necessarily increased focus on the control of inflation. This is so since if inflation shocks contribute to interest rate variability in an IT era, then inflation expectations would prevent inflation from deviating much from the inflation target; this would imply that the central bank is less focused on inflation, not more! Consequently, this would clearly suggest "that the VAR evidence in the paper, tells us little about the impact of inflation targeting on the conduct of monetary policy" (Mishkin, p. 150).

Ball and Sheridan (2003) measure the effects of IT on macroeconomic performance in the case of twenty OECD countries, seven of which adopted IT in the 1990s. They conclude that they are unable to find any evidence that IT improves economic performance as measured by the behaviour of inflation, output and interest rates. Not that better performance was not evident for the IT countries. Clearly, inflation fell in these countries and became more stable; and output growth stabilised during the IT period as compared to the pre-IT period. But then the same experience was evident for countries that did not adopt IT. Consequently, better performance must have been due to something other than IT. When performance is compared, it is larger for IT countries than for non-IT countries, a result that is similar in many ways to that of Neumann and von Hagen (2002); the latter see it as a further benefit of IT. ${ }^{18}$ Ball and Sheridan (2003), however, suggest that the evidence they produce, and by implication that of Neumann and von Hagen (2002), does not support even this modest claim of IT benefit. This is explained by resorting to further evidence of countries with unusually high and unstable inflation rates where this problem disappears irrespective of their adoption of IT. Indeed, controlling for this effect, the apparent benefit disappears altogether. The apparent success of IT countries is merely due to them having "high initial inflation and large decreases, but the decrease for a given initial level looks similar for targeters and non-targeters" (Ball; Sheridan, 2003, p. 16). The same result prevails in the case of inflation variability and inflation persistence. As to whether IT affects output behaviour and interest rates, Ball and Sheridan (2003) conclude in the same vain that IT does not affect output growth or output variability, nor does it affect interest rates and their variability. ${ }^{19}$

(18) It is actually viewed by Neumann and von Hagen (2002) as evidence of 'convergence' in that on average IT countries converge to the inflation rates of the non-IT countries in the targeting period.

(19) A related recent study by Bodkin and Neder (2003), examines IT in the case of Canada for the period 1980-1989 and 1990-1999 (the IT period). Their results, based on graphical analysis, clearly indicate that inflation over the IT period did fall, but at a significant cost of unemployment and output. A result which leads the authors to the conclusion that a great deal of doubt is cast "on the theoretical notion of the supposed long-run neutrality of money", an important, if not the most important, ingredient of the theoretical IT framework. The also, suggest that the "deleterious real effects (higher unemployment and ..... lower growth) during the decade under study suggests that some small amount of inflation (say in the range of 3 to 5 percent) may well be beneficial for a modern economy" (p. 355). 
Philip Arestis / Malcolm Sawyer

\section{Summary and conclusions}

We have argued in this paper that IT is closely associated with the NCM. We have located the theoretical foundations of IT and identified a number of weaknesses and reservations with it. We have also assessed critically the empirical work undertaken on IT. The overall evidence on IT is that it has gone hand-in hand with low inflation (King, 1997b), but there is still the question of causation, of course, that needs further work. But there is still the possibility that IT 'locks in' low inflation. The available evidence would suggest that a central bank does not need to pursue an IT strategy to achieve this and other objectives. Non-IT central banks have done as well, if not better in some cases. It would, thus, appear that Mishkin's (1999) premature statement that the reduction of inflation in IT countries "beyond that which would likely have occurred in the absence of inflation targets" (p. 595), is not supported by any theoretical reasoning or empirical evidence. We would, therefore, conclude overall along with Ball and Sheridan (2003) that the recent 'low-inflation' era is not different for IT and nonIT countries. Consequently, IT has been a great deal of fuss about really very little!

\section{References}

AKERLOF, G. A.; DICKENS, W. T.; PERRY, G. L. The macroeconomics of low inflation. Brookings Papers on Economic Activity, 1, p. 1-76, 1996.

ALCHIAN, A. A.; KLEIN, B. On a correct measure of inflation. Journal of Money, Credit and Banking, v. 5, n. 1, p. 173-191, 1973.

ALESINA, A. F.; BLANCHARD, O.; GALI, J.; GIAVAZZI, F.; UHLIG, H. Defining $a$ macroeconomic framework for the Euro area: monitoring the European Central Bank 3. London: Centre for Economic Policy Research, 2001.

ANGELONI, I.; KASHYAP, A.; MOJON, B.; TERLIZZESE, D. Monetary transmission in the Euro Area: where do we stand. European Central Bank Working Paper Series, n. $114,2002$.

ARESTIS, P.; CAPORALE, G. M.; CIPOLLINI, A. Is there a trade-off between inflation and output gap? The Manchester School of Economic and Social Research, v. 70, n. 4, p. 528-545, 2002.

; KARAKITSOS, E. The post-bubble US economy: implications for financial markets and the economy. London: Palgrave Macmillan, 2004.

; SAWYER, M. Can monetary policy affect the real economy? Levy Economics Institute of Bard College, Sept. 2002. (Working Paper, n. 355).

; SAWYER, M. The nature and role of monetary policy when money is endogenous. Levy Economics Institute of Bard College, Mar. 2003a. (Working Papers Series, n. 374). 
ARESTIS, P.; SAWYER, M. Does the stock of money have any causal significance? Banca Nazionale del Lavoro Quarterly Review, v. LVI, n. 225, p. 113-136, 2003 b. v. 26, n. 1 , p. $3-25,2003$ c.

Reinventing fiscal policy. Journal of Post Keynesian Economics,

$$
\text { ; }
$$
. The case for fiscal policy. Levy Economics Institute of Bard College, May, 2003d. (Working Papers Series, n. 382).

; _ . On the effectiveness of monetary policy and fiscal policy. Levy Economics Institute of Bard College, Jan., 2003e. (Working Papers Series, n. 369).

BALL, L.; SHERIDAN, N. Does inflation targeting matter? Cambridge, MA: National Bureau of Economic Research, 2003. (NBER Working Paper Series, n. 9577).

BANK OF ENGLAND. Economic models at the Bank of England. London, 1999.

Economic models at the Bank of England. London, Sept. Update, 2000.

BARRO, R. J.; GORDON, D. B. A positive theory of monetary policy in a natural rate model. Journal of Political Economy, v. 91, n. 3, p. 589-619, 1983.

BEAN, C. Asset prices, financial imbalances and monetary policy: are inflation targets enough? In: RICHARDS, T.; ROBINSON, T. (Ed.). Asset prices and monetary policy. Reserve Bank of Australia, 2003. p. 48-76.

BERNANKE, B. S. 'Constrained discretion' and monetary policy. Remarks before the Money Marketeers of New York University, New York, Feb. ${ }^{\text {rd }}$., 2003a.

A perspective on inflation targeting. Remarks at the Annual Washington Policy Conference of the National Association of Business Economists, Washington, DC, 25 Mar., 2003b.

; BLINDER, A. S. Credit, money and aggregate demand. American Economic Review, Papers and Proceedings, v. 78, n. 2, p. 435-439, 1988.

; GERTLER, M. Agency costs, net worth, and business fluctuations. American Economic Review, v. 79, n. 1, p. 14-31, 1989.

; _ Monetary policy and asset price volatility. In: NEW Challenges for Monetary Policy, Proceedings of the Symposium Sponsored by the Federal Reserve Bank of Kansas City, Jackson Hole, Wyoming, Aug. 26-28, 1999. p. 77-128.

; __. Monetary policy and asset price volatility. Cambridge, MA: National Bureau of Economic Research, 2000. (NBER Working Paper, n. 7559).

; ___ GILCHRIST, S. The financial accelerator in a quantitative business cycle framework. In: TAYLOR, J.; WOODFORD, M. (Ed.). Handbook of macroeconomics. Amsterdam: North Holland, 1999. v. 1.

; LAUBACH, T.; MISHKIN, F. S.; POSEN, A. Inflation targeting: lessons from the international experience. Princeton: Princeton University Press, 1999.

; MISHKIN, F. S. Inflation targeting: a new framework for monetary policy? Journal of Economic Perspectives, v. 11, n. 2, p. 97-116, 1997. 
Philip Arestis / Malcolm Sawyer

BLINDER, A. S. Central banking in theory and practice. Cambridge, Massachusetts: MIT Press, 1998.

BODKIN, R. G.; NEDER, A. E. Monetary policy targeting in Argentina and Canada in the 1990s: a comparison, some contrasts, and a tentative evaluation. Eastern Economic Journal, v. 29 , n. 3, p. 339-358, 2003.

BOIVIN, J.; GIANNONI, M. Assessing changes in the monetary transmission mechanism: a VAR approach. Federal Reserve Bank of New York Economic Policy Review, v. 8, n. 1, p. 97-111, 2002a.

; $\quad$ Has monetary policy become less powerful? Federal Reserve Bank of New York Staff Report, n. 144, Mar. 2002b.

BORDO, M. D.; JEANNE, O. Monetary policy and asset prices: does 'Benign Neglect' make sense? Washington, D.C.: International Monetary Fund, 2002. (IMF Working Paper, n. 02/225).

CALVO, G. On the time consistency of optimal policy in the monetary economy. Econometrica, v. 46, n. 4, p. 1411-1428, 1978.

CECCHETTI, S. G.; GENBERG, H.; LIPSKY, J.; WADHWANI, S. B. Asset prices and Central Bank policy. Geneva Reports on the World Economy, International Centre for Monetary and Banking Studies and Centre for Economic Policy Research, Geneva and London, n. 2, 2000.

; EHRMANN, M. Does inflation targeting increase output volatility? An international comparison of policymakers' preferences and outcomes. Santiago: Central Bank of Chile, 2000. (Working Paper, n. 69).

CLEWS, R. Asset prices and inflation. Bank of England Quarterly Bulletin, p. 178-185, Summer 2002.

CLIFTON, E. V.; HYGINUS, L.; WONG, C-H. Inflation targeting and the unemployment -inflation trade-off. Washington, DC: International Monetary Fund, 2001. (IMF Working Paper, 01/166).

CORBO,V.; LANDERRRETCHE, M. O.; SCHMIDT-HEBBEL, K. Assessing inflation targeting after a decade of world experience. Santiago: Central Bank of Chile, 2001. Mimeografado.

; _ _ _ Does inflation targeting make a difference? In: LOAYZA, N.; SAITO, R. (Ed.). Inflation targeting: design, performance, challenges. Santiago: Central Bank of Chile, 2002.

DEBELLE, G.; FISCHER, S. How independent should a Central Bank be? In: FUHRER, J. C. (Ed.). Goals, guidelines, and constraints facing monetary policymakers. Boston: Federal Reserve Bank of Boston, 1994. p. 195-221.

DUISENBERG, W. Introductory statement, and questions and answers. ECB Press Conference, 8 May, Frankfurt, Germany, 2003.

DUPOR, W. Nominal price versus asset price stabilisation. University of Pennsylvania, 2002. Mimeografado. 
FEDERAL RESERVE BANK OF NEW YORK Financial innovation and monetary transmission. Economic Policy Review, v. 8, n. 1, Proceedings of a Conference Sponsored by the Federal Reserve Bank of New York, 2002.

FISCHER, S. Modern central banking. In: CAPIE F.; GOODHART, C. A. E.; FISCHER, S.; SCHNADT, N. (Ed.). The future of Central Banking. Cambridge: Cambridge University Press, 1994. p. 262-308.

FORDER, J. The theory of credibility: confusions, limitations, and dangers. International Papers in Political Economy, v. 7, n. 2, p. 3-40, 2000.

FRACASSO, A.; GENBERG, H.; WYPLOSZ, C. How do central banks write? An evaluation of inflation reports by inflation targeting central banks. Geneva Reports on the World Economy Special Report 2, London: Centre for Economic Policy Research, 2003.

GALBRAITH, J. K. The inflation obsession: flying in the face of the facts. Foreign Affairs, v. 78, n. 1, p. 152-156, 1999.

GORDON, R. J. The time-varying NAIRU and its implications for economic policy. Journal of Economic Perspectives, v. 11, n. 1, p. 11-32, 1997.

GOODHART, C. A. E. What weight should be given to asset prices in the measurement of inflation. Economic Journal, v. 111, n. 472, p. F335-F356, 2001.

GRAMLICH, E. M. Inflation targeting. Remarks before the Charlotte Economics Club, Charlotte, North Carolina, 13 Jan. 2000.

GREENSPAN, A. Economic volatility. Speech given to a Symposium Sponsored by the Federal Reserve Bank of Kansas City, Jackson Hole, Wyoming, 2002.

GHOSH, A.; PHILLIPS, S. Warning: inflation may be harmful to your growth. IMF Staff Papers, v. 45, n. 4, p. 672-710, 1998.

HALL, S. Credit channel effects in the monetary transmission mechanism. Bank of England Quarterly Bulletin, p. 442-448, Winter 2001.

HM TREASURY. Policy frameworks in the UK and EMU: EMU Study. London: HMSO, 2003. Also available at: www.hm-treasury.gov.uk.

JOHNSON, D. R. The effect of inflation targeting on the behaviour of expected inflation: evidence from an 11 Country Panel. Journal of Monetary Economics, v. 49, p. 1521-1538, 2002.

KUTTNER, K. N.; MOSSER, P. C. The monetary transmission mechanism: some answers and further questions. Federal Reserve Bank of New York Economic Policy Review, v. 8, n. 1, p. 15-24, 2002.

KING, M. Changes in UK monetary policy: rules and discretion in practice. Journal of Monetary Economics, v. 39, p. 81-87, 1997a.

The inflation target five years on. Lecture delivered at the London School of Economics, 29 Oct. 1997b.

No money, no inflation - The role of money in the economy. Bank of England

Quarterly Bulletin, v. 42, n. 2, p. 162-177. Reprinted in: MIZEN, P. (Ed.). Central 
Philip Arestis / Malcolm Sawyer

banking, monetary theory and practice: essays in honour of Charles Goodhart. Cheltenham: Edward Elgar Publishing, 2003. 2002a. v. 1.

KING, M. The inflation target ten years on. Bank of England Quarterly Bulletin, v. 42, n. 4, p. 459-474, Summer 2002b.

The institution of monetary policy - The Elly Lecture 2004. Presented at the American Economic Association Annual Meeting, San Diego, 4 Jan. 2004a.

Comments on 'Risk and Uncertainty in Monetary Policy' by Alan Greenspan. Presented at the American Economic Association Annual Meeting, San Diego, 4 Jan. 2004b.

KYDLAND, F.; PRESCOTT, E. C. Rules rather than discretion: the inconsistency of optimal plans. Journal of Political Economy, v. 85, n. 3, p. 473-492, 1977.

LEIDERMAN, L.; SVENSSON, L. E. O. (Ed.). Inflation targets. London: Centre for Economic Policy Research, 1995.

MCCALLUM, B. T. Monetary policy analysis in models without money. Federal Reserve Bank of St. Louis Review, v. 83, n. 4, p. 145-160, 2001.

MEYER, L. Inflation targets and inflation targeting. Remarks at the University of California at San Diego Economics Roundtable, San Diego, California, 17 Jul. 2001.

MISHKIN, F. S. International experiences with different monetary policy regimes. Journal of Monetary Economics, v. 43, p. 579-605, 1999.

What should central banks do? Federal Reserve Bank of St. Louis Review, v. 82, n. 6 , p. $1-13,2000$.

. Does inflation targeting matter? Commentary. Federal Reserve Bank of St. Louis Review, v. 84, n. 4, p. 149-153, 2002.

; POSEN, A. S. Inflation targeting lessons from four countries. Federal Reserve Bank of New York Economic Policy Review, v. 3, n. 1, p. 9-117, 1997.

NEUMANN, M. J. M.; VON HAGEN, J. Does inflation targeting matter? Federal Reserve Bank of St. Louis Review, v. 84, n. 4, p. 127-148, 2002.

PALLEY, T. I. A post Keynesian framework for monetary policy: why interest rate operating procedures are not enough. Presented to the Conference on Economic Policies: Perspectives from Keynesian Heterodoxy, Dijon, France, 14-16 Nov. 2002. Revised Mar. 2003.

ROGOFF, K. The optimal degree of commitment to an intermediate monetary target. Quarterly Journal of Economics, v. 100, n. 4, p. 1169-1189, 1985.

ROTEMBERG, J. J.; WOODFORD, M. An optimization-based econometric framework for the evaluation of monetary policy. NBER Macroeconomics Annual 1997, National Bureau of Economic Research, Cambridge, MA, p. 297-346, 1997.

RUDEBUSCH, G. D.; SVENSSON, L. E. O. Policy rules for inflation targeting. In: TAYLOR, J. B. (Ed.). Monetary policy rules. Chicago: Chicago University Press, 1999.

ROOSA, R. V. Interest rates and the Central Bank. In: MONEY, trade and economic growth: essays in honour of John Henry Williams. New York: Macmillan, 1951. p. 270-295. 
SAWYER, M. The NAIRU: a critical appraisal. International Papers in Political Economy, v. 6, n. 2, p. 1-40. Reprinted in: ARESTIS, P.; SAWYER, M. (Ed.). Money, finance and capitalist development. Aldershot: Edward Elgar, 1999. p. 220-254.

SCHEATER, A.; STONE, M. R.; ZELMER, M. Adopting inflation targeting: practical issues for emerging market countries. ,Washington, DC: International Monetary Fund, 2000. (IMF Occasional Paper, n. 202).

STIGLITZ, J. Too important for bankers: Central Banks' ruthless pursuit of price stability holds back economic growth and boosts unemployment. The Guardian, 10 Jun. 2003.

; WEISS, A. Credit rationing in markets with imperfect information. American Economic Review, v. 71, n. 3, p. 393-410, 1981.

SVENSSON, L. E. O. Inflation forecast targeting: implementing and monitoring inflation targets. European Economic Review, v. 41, p. 1111-1146, 1997.

. Inflation targeting as monetary policy rule. Journal of Monetary Economics, v. 43, p. 607-654, 1999.

What is wrong with Taylor rules? Using judgement in monetary policy through targeting rules. Journal of Economic Literature, v. XLI, n. 2, p. 426-477, 2003.

; WOODFORD, M. Implementing optimal policy through inflation-forecast targeting. Cambridge, MA: National Bureau of Economic Research, 2003. (NBER Working Paper Series, n. 9747).

TAYLOR, J. B. Discretion versus policy rules in practice. Carnegie-Rochester Conference Series on Public Policy, p. 195-214, Dec. 1993.

- A historical analysis of monetary policy rules. In: TAYLOR, J. B. (Ed.). Monetary policy rules. Chicago: Chicago University Press, 1999.

VAN ELS, P.; LOCARNO, A.; MORGAN, J.; VILLETELLE, J-P. Monetary policy transmission in the Euro Area: what do aggregate and national structural models tell us? European Central Bank Working Paper Series, n. 94, 2001.

VOLCKER, P. Monetary policy transmission: past and future challenges. Federal Reserve Bank of New York Economic Policy Review, v. 8, n. 1, p. 7-11, 2002.

WOODFORD, M. Optimal monetary policy inertia. Cambridge, MA: National Bureau of Economic Research, 1999. (NBER Working Paper Series, n. 7261).

The Taylor rule and optimal monetary policy. American Economic Review,

Papers and Proceedings, v. 91, n. 2, p. 232-237, 2001. 